Harmful Algae

February 2018, Volume 72 Pages 1-13

http://dx.doi.org/10.1016/i.hal.2017.12.005

http://archimer.ifremer.fr/doc/00416/52786/

(C) 2017 Elsevier B.V. All rights reserved

Archimer

http://archimer.ifremer.fr

\title{
Realized niche analysis of phytoplankton communities involving HAB: Phaeocystis spp. as a case study
}

\author{
Karasiewicz Stéphane ${ }^{1,{ }^{*}}$, Breton Elsa ${ }^{1}$, Lefebvre Alain ${ }^{2}$, Hernandez Farinas Tania ${ }^{3}$, \\ Lefebvre Sébastien ${ }^{1,4}$
}

${ }^{1}$ Univ Lille, Univ Littoral Cote dOpale, CNRS, LOG,UMR 8187, F-62930 Wimereux, France.

${ }^{2}$ Ifremer, Lab Environm \& Ressources Ctr Manche Mer Nord, 150 Quai Gambetta,BP 699, F-62321

Boulogne Sur Mer, France.

${ }^{3}$ Ifremer, Lab Environm Ressources Normandie, Ave Gen Gaulle,BP 32, F-14520 Port En Bessin, France.

${ }^{4}$ Ifremer, Lab Ressources Halieut, 150 Quai Gambetta BP 699, F-62321 Boulogne Sur Mer, France.

*Corresponding author : Stéphane Karasiewicz, email address : stephane.karasiewicz@wanadoo.fr

\begin{abstract}
:
The link between harmful algal blooms, phytoplankton community dynamics and global environmental change is not well understood. To tackle this challenging question, a new method was used to reveal how phytoplankton communities responded to environmental change with the occurrence of an harmful algae, using the coastal waters of the eastern English Channel as a case study. The great interannual variability in the magnitude and intensity of Phaeocystis spp. blooms, along with diatoms, compared to the ongoing gradual decrease in anthropogenic nutrient concentration and rebalancing of nutrient ratios; suggests that other factors, such as competition for resources, may also play an important role. A realized niche approach was used with the Outlying Mean Index analysis and the dynamics of the species' realized subniches were estimated using the Within Outlying Mean Indexes calculations under low $(\mathrm{L})$ and high $(\mathrm{H})$ contrasting Phaeocystis spp. abundance. The Within Outlying Mean Indexes allows the decomposition of the realized niche into realized subniches, found within the subset of habitat conditions and constrained by a subset of a biotic factor. The two contrasting scenarios were characterized by significantly different subsets of environmental conditions and diatom species (BV-step analysis), and different seasonality in salinity, turbidity, and nutrients. The subset $L$ environmental conditions were potentially favorable for Phaeocystis spp. but it suffered from competitive exclusion by key diatom species such as Skeletonema spp., Thalassiosira gravida, Thalassionema nitzschioides and the Pseudo-nitzchia seriata complex. Accordingly, these diatoms species occupied $81 \%$ of Phaeocystis spp.'s existing fundamental subniche. In contrast, the greater number of diatoms, correlated with the community trend, within subset $\mathrm{H}$ exerted a weaker biological constraint and favored Phaeocystis spp. realized subniche expansion. In conclusion, the results strongly suggest that both abiotic and biotic interactions should be considered to understand Phaeocystis spp. blooms with greater consideration of the preceeding diatoms. HABs needs must therefore be studied as part of the total phytoplankton community.
\end{abstract}




\section{Highlights}

- Phaeocystis spp.' has a smaller realized subniche in events of low abundance blooms. Phaeocystis spp.' small realized subniche is due to an important biological constraint. Higher diversity of the diatom community as a weaker biological constraint. The preceeding key diatom community seemed controlled by the environment. The preceeding diatom competitive ability controls the bloom of Phaeocystis spp.

Keywords: Harmful algae bloom, WitOMI, Subniche, Diatoms, Biotic interaction, Eastern English Channel 


\section{Introduction:}

2 The unprecedented rate of global environmental change (Drijfhout et al., 2015), is potentially increasing the 3 spread and impact of harmful algae blooms (HAB) worldwide (Fu et al., 2012; Hallegraeff, 2010; Wells et al., 4 2015). Attempts to link HABs or undesirable species and anthropogenically-altered environments have often 5 been unclear and contradictory (Anderson, 2009; Davidson et al., 2012; Gowen et al., 2012; Wells et al., 2015). 6 Moreover, the role of biotic interactions in shaping HABs, such as competition for resources, is still poorly studied. 7 Yet, the variability in the magnitude and duration of reported HAB blooms emphasizes the idea that other factors, aside from abiotic variables, play an important role in driving HABs (Bianchi et al., 2000; Borkman et al., 2016; Yin, 2003). Previous research strategies, methods and hypotheses of how environmental pressures mechanistically affect HAB species (Wells et al., 2015) have used modelling (Passy et al., 2016), experiments (Veldhuis et al., 1991), in situ measurements (Houliez et al., 2013), and remote sensing imaging (Kurekin et al., 2014) to explore these links. The former studies were based on the hypothesis that HABs could be predicted from environmental variables only.

Hutchinson's niche concept (1991) allows studying the link between global changes and the phytoplankton community in relation to HABs. Among several multivariate methods available for niche analysis (Braak, 1986; e.g. Calenge et al., 2005; Ter Braak, 1987), Hernández-Fariñas et al. (2015) used the niche through using the Outlying Mean Index (OMI) (Dolédec et al., 2000), assessing the niche of 35 phytoplankton species, including diatoms, along the French coast. Recently, the Within Outlying Mean Indexes calculations (WitOMI; Karasiewicz et al., 2017) was developed as a refinement of the OMI analysis and provides estimations of niche shift and/or conservatism of a community under different subsets of habitat conditions (temporal and/or spatial). The WitOMI calculates the species' realized subniche dynamics (species' niche occupation within subset habitat conditions) within the realized niche resulting from the OMI analysis after selecting subsets. The realized subniches are, therefore, comparable under the same environmental gradients. The decomposition of the niche into subniches, with the WitOMI allows one to observe and measure the part of the existing fundamental subniche that is not used by the species despite being available. The unused part of the existing fundamental subniche is considered as the subset's biological constraints (e.g. competition, predation, mutualism, dispersal and colonization) (Karasiewicz et al., 2017). This last method deciphers the effect of selected environmental factors from unknown biotic factors and is fully adapted to explore the phytoplankton community response to climate change along with HABs. 
The study aim was to use the Within Outlying Mean Indexes calculations (Karasiewicz et al., 2017) to understand how the environment influences harmful species realized niches. The method should reveal how the phytoplankton community before and/or during HABs, can influence the harmful algae realized niche. The estimation of the biological constraint should reveal the impact of biological processes on the HAB, providing further insight into the implications on potential competitors. This new method of HAB investigation will be tested with the case study of Phaeocystis spp. in the Eastern English Channel. In these waters, the bulk of biomass is represented by the diatom community and Phaeocystis spp. (Grattepanche et al.,2011). The genus Phaeocystis is one of the most globally distributed marine haptophytes (Lancelot et al., 1994). Although non-toxic (Cadée and Hegeman, 2002), it is classified as undesirable because three species (i.e. P. globosa, P.pouchetii and P.antarctica) are capable of forming large gelatinous colonies, creating impressive foam layers along beaches during bloom collapse (Blauw et al., 2010). This accumulation of excessive organic matter could result in alteration both in the benthic and pelagic compartments. More recently, Breton et al. (2017) suggested with a trait-based approach, that competitive exclusion prevails during Phaeocystis spp.'s blooms. The diatoms' taxonomic level, however, was not fine enough to reveal the potential resource competitors of Phaeocystis spp. (Breton et al. 2017). To date, no studies have considered the competitive interactions as a possible HAB control.

\section{Methods:}

\subsection{Data set:}

The data were collected as part of the French REPHY-IFREMER (Réseau d'Observation de Surveillance du Phytoplancton et des Phycotoxines) and the Regional Nutrients Monitoring Network (SRN, 2017). Water samples were acquired from a fortnightly to monthly frequency from 1996-2012, between 0 and 1 m depth, along with physical measurements, and were completed with chemical analyses. The environmental variables measured included, seawater temperature $\left({ }^{\circ} \mathrm{C}\right)$, salinity (measured using the Practical Salinity Scale), turbidity (NTU), inorganic nutrient concentrations (dissolved inorganic nitrogen, silicate, and phosphate in $\mu \mathrm{mol.L^{-1 }}$ ) and photosynthetically active radiation $\left(\mathrm{PAR}, \mathrm{W} \cdot \mathrm{m}^{-2}\right)$. Note that PAR is the cumulative sum over the five days preceding phytoplankton sampling. In regards to the quantitative phytoplankton analyses, samples were fixed with Lugol's solution and counted according to the Utermöhl method (Utermöhl, 1958). Organisms were identified to the lowest possible taxonomic level. Taxa that are difficult to discriminate with optical microscopy were grouped (e.g. Pseudo-nitzschia seriata complex). In addition, experts identified and counted (cells/L) phytoplankton taxa bigger than $20 \mathrm{~mm}$, and also smaller size species that create chain structures or form a colonies (e.g. Phaeocystis spp.). Further details about sampling and processing of phytoplankton and physicochemical parameters are 
available in the literature (Lefebvre et al., 2011; Belin and Neaud-Masson, 2012). Unlike Hernández-Fariñas et al. (2015), this study focused on the coastal station 1 of Boulogne-sur-mer because the waters are known for recurrent Phaeocystis blooms (Figure 1).

\subsection{Subsets creation:}

In order to understand the impact of biotic and abiotic factors on the Phaeocystis spp. realized niche, two data subsets that gathered years of high and low Phaeocystis spp. annual mean abundance events were created (named hereafter subset $\mathrm{H}$ and $\mathrm{L}$ for high and low respectively). The years of Phaeocystis spp. intermediate mean annual abundance were left-out for the rest of the study. This methodology enables deciphering the conditions and the potential resources used by the diatom community and Phaeocystis spp. in contrasted events. Each subset has its own environmental habitat conditions and phytoplankton communities $(\mathrm{n}=53$ sampling units for subset $\mathrm{L}$ and n=71 for subset H). Additionally, a non-random BV-STEP analysis (Clarke et al., 2001) with 10000 reiterations was performed to extract the species that correlated most with the entire diatom community during subsets L and H. The diatom species best representing the community under both subsets were used to describe the succession under each subset. Herein, the study does not try to determine the conditions under which the ecosystem is dominated by Phaeocystis spp. (e.g., the ratio between diatoms species biomass and Phaeocystis spp.) as in (Lefebvre et al., 2011), but rather the habitat conditions within which the species can reach high abundances. The environmental habitat conditions are the environmental conditions measured at time $t$ of the sampling.

\subsection{Niche and subniche analysis:}

An OMI analysis (Dolédec et al., 2000) was performed including all the sampling dates in order to reflect most of the environmental variability within the OMI axes. Only the significant species identified by the BV step analysis above were used further in the study. The subniche estimations within the subsets $\mathrm{H}$ and $\mathrm{L}$ (see below) were calculated with the Within Outlying Mean Indexes calculations (WitOMI) (Karasiewicz et al., 2017). Species' subniche dynamics were estimated by comparing the subniche parameters (marginality and tolerance) to the origin $G$ (WitOMIG and Tol), which is the representation of a uniformly distributed theoretical species that would occur at all available habitat conditions (i.e. ubiquitous) (Dolédec et al.,2000). Second, the estimation of the subniche parameters to the subset origin $G_{K}$ (WitOMI $G_{K}$ and Tol), which is the representation of the subset mean habitat conditions used by a hypothetical species (Karasiewicz et al., 2017), revealing the species distribution within the subset habitat conditions. The statistical significance of marginality was tested using a Monte Carlo permutation procedure (Manly, 1997) with 10000 permutations. 


\subsection{Biological constraint:}

The existing fundamental subniche, $\mathbf{S}_{P}$, corresponds to the realized niche, $\mathbf{N}_{R}$, which is reduced abiotically by the subset habitat conditions, $\mathbf{K}$. Therefore, $\mathbf{S}_{P}$ includes the subset biotic factor, $\mathbf{S}_{B}$, reducing $\mathbf{S}_{P}$ into the realized subniche, $\mathbf{S}_{R}$ (Figure 2). In summary:

$$
\mathbf{S}_{R} \bigcup \mathbf{S}_{B}=\mathbf{S}_{P}=\mathrm{K} \bigcap \mathbf{N}_{R}
$$

$\mathbf{S}_{B}$ represents negative biological interactions (e.g., predation, competition, parasitism, etc.), the species dispersal limitation (i.e., lack of time for migration), or occupancy by another species (Peterson, 2011) (Figure 2). The $\mathbf{S}_{B}$ unit is in percentage of $\mathbf{S}_{P}$, and represents the biological constraint exerted on the subniche. Therefore, under the subset habitat conditions $\mathrm{H}$ or L, the biological constraint exerted on Phaeocystis spp. subniches, and the effect of some other unselected abiotic variables, can be discussed.

All analyses and graphical representations were performed using R software (R Core Team, 2013) with the packages "ade4" (Dray and Dufour, 2007) and "subniche" available for free on the CRAN repository www.cran.r-project.org and on GitHub www.github.com/KarasiewiczStephane/WitOMI.

\section{Results:}

\subsection{Subset habitat conditions:}

Low $\left(<50\right.$ cells.L $\left.{ }^{-1}\right)$ and high $\left(>160\right.$ cells.L $\left.{ }^{-1}\right)$ mean annual Phaeocystis spp. abundance events (named hereafter subset L and H) occurred on four and five occasions, respectively (L: 1996, 1997, 2000, and 2005, H: 2001, 2004, and 2010-2012; Figure 3). The non-random BV-step analysis revealed that 7 diatom species were correlated to the overall pattern of the community (Gud, Gus, Par, Pss, Ske, Thn, and Thg, with $\rho=0.97$; See code in Table 1) in subset L, while 9 diatom species were relevant in subset H (Cha, Dyt, Gud, Gus, Led, Nit, Par, Ske, and Thn, with $\rho=0.96)$. Five species, Gud, Gus, Par, Ske, Thn were common to the two contrasting environmental conditions, leading to 11 species of interest for the rest of the study. Two species occurred only in subset L (Thg and Pss) and four species occurred only in subset H (Dit, Cha, Led, and Nit)(See code in Table 1).

Although the two subsets showed similar increases in temperature and PAR, varying from 5.8 to $19.9^{\circ} \mathrm{C}$ and from 8.5 to $6.110^{3}$.W. $\mathrm{m}^{2}$ respectively (Figure $4 \mathrm{~A}$ and $4 \mathrm{~B}$ ), the two subsets differed in turbidity, salinity and nutrient concentrations. Accordingly, subset L displayed higher turbidity but lower salinity than subset H (Figure 4C-D). Moreover, nutrient concentrations were significantly lower and decreased faster in subset $\mathrm{H}$ than in subset $\mathrm{L}$ 
during late winter-early spring (Figure $2 \mathrm{E}-\mathrm{H}$ ). Phosphate concentration had an overall higher concentration in subset L (Figures $4 \mathrm{~F}$ ). The sum of nitrate and nitrite concentrations was similar in January and December in both subset $\mathrm{L}$ and $\mathrm{H}$, but the overall concentration was higher in subset $\mathrm{L}$ than in $\mathrm{H}$ (Figure 4G). The seasonal trends of silicate concentration were similar in the two subsets, although it decreased faster the rest of the year in subset $\mathrm{H}$ than in subset $\mathrm{L}$ (Figure $4 \mathrm{H}$ ). The DIN:PO 4 followed a unimodal trend with a maximum in April (DIN:PO $4: 88$ ) and March ( DIN:PO $\mathrm{PO}_{4}: 70$ ) for subset L and $\mathrm{H}$ respectively (Figure 4I). The DIN:Si was higher in subset L than in $\mathrm{H}$ with a maximum in April (DIN:Si: 59) and March (DIN:Si: 30) respectively.

\subsection{Niche analysis (OMI):}

The OMI analysis revealed that the realized niches of the 11 diatom species of interest, depicted by the BV-step analysis, and of Phaeocystis spp. were significant (Table 1). The first two axis of the OMI analysis represented $87 \%$ of projected inertia, of which OMI1 represented $74 \%$. OMI1 was mainly explained by nutrients and turbidity (Figure 5C), while OMI2 was mainly explained by PAR, temperature and salinity. The seasonal effect can be visualized by the environmental trajectories of subset $\mathrm{H}$ and $\mathrm{L}$ (Figure $5 \mathrm{~B}$ ). The environmental trajectory of subset $\mathrm{H}$ had a higher position and better resembled a full cycle than subset $\mathrm{L}$, which went "back on track" (Figure 5B).

The species Ske, Thg and Thn were typical of late winter-early spring and were, as expected, low on the OMI1 axis (on the left side, Figure 5A). Their niches were explained by high nutrient concentrations and turbidity, but low temperature, PAR and salinity. These three species have the highest niche breadth (Tol Ske: 3.52, Thn: 3.35, Thg: 3.14) (Table1). The niches of Dit and Cha, Par and Nit were related to intermediate values of OMI1 (lower values of nutrients and turbidity; Figure 5A). They distributed themselves vertically along the OMI2 by their preferences for higher salinity, temperature and PAR (higher temperature and PAR downwards ; Figure 5A). The species with the lowest marginality were Nit and Par (OMI: 0.06 and 0.09 for Nit and Par respectively). The niches of Pss, Gud, Gus and Phae were characterized by low nutrient concentrations and turbidity but differed from each other in salinity, PAR and temperature affinities. The niche position of Phae was characterized by relatively high salinity but intermediate temperature and PAR, while the other species were rather defined by lower salinity and higher temperature and PAR along the OMI2 axis. The niche of Led, which is typically a summer diatom species was characterized by the lowest nutrient concentrations and turbidity, high salinity, and intermediate temperature and PAR. As a result, Led was characterized by a high marginality (OMI: 2.231). 
3.3. Subniche calculations (WitOMI):

Phaeocystis spp.'s subniche position significantly shifted and the subniche breadth expanded from subset L to $\mathrm{H}$ (WitOMIG: 2.64 and 2.11; Tol: 0.59 and 0.64 for subset $\mathrm{L}$ and $\mathrm{H}$ respectively) (Figure 6). The marginality (WitOMI $G$ ) showed that Phaeocystis spp. used a more common habitat in subset $\mathrm{H}$ than in L. This suggest that the species has a preference for the environmental habitat conditions found in subset H over L (Figure 6). Considering the subsets independently, the subniche position from the average subset habitat conditions, $G_{K}$ was much greater in subset $\mathrm{L}$ than $\mathrm{H}\left(\mathrm{WitOMI}_{K}: 3.24\right.$ and 0.59 from subset $\mathrm{L}$ and $\mathrm{H}$ respectively). In subset $\mathrm{H}$, Phaeocystis spp. used a more common habitat favoring its development (237 cells.L $\mathrm{L}^{-1}$, Table 2$)$. On the other hand, the habitat preference in subset L, which is atypical for the environmental habitat conditions within subset L, is not well suited for Phaeocystis spp. (29 cells.L-1 ${ }^{-1}$ Table 2).

The different WitOMIG values for the common diatom species (Ske, Thn, Par, Gud, Gud), expressed a change in subniche position (Table 2). Meanwhile, the tolerance from $G$ increased for Gud, while it decreased for Gus, Par, Ske and Thn (Table 2). The low $\mathrm{WitOMI}_{K}$ values in the environmental habitat conditions subset $\mathrm{H}$ were preferable for Thn, Par, Gud, and Gus, compared to the environmental habitat conditions of subset L. The opposite pattern occurred for Ske (Table 2). Ske had a preference for the environmental habitat conditions of subset L, as the species' mean abundance, which was higher in subset L, likely reflected the species' habitat suitability. The species Par and Thn had higher mean abundance in subset H, while Gud and Gus had stable mean abundances (Table 2).

Concerning species that occurred in only one subset, Pss had one of the lowest marginalities and intermediate tolerance (WitOMI $G_{K}: 0.28$ and Tol: 1.69), while Thg had an intermediate marginality with high tolerance (WitOMI $G_{K}: 0.78$ and Tol: 4.13), in subset L (Table 2). In subset $\mathrm{H}$, marginality of low for Nit and Cha, intermediate for Dit, and high for Led $\left(\mathrm{WitOMI}_{K}\right.$ : 0.14, 0.31, 0.58, and 2.05 for Nit, Cha, Dit and Led respectively) (Table 2). Led had an intermediate tolerance while Nit, Cha and Dit had high tolerance in subset $\mathrm{H}$ (Table 2).

The environmental habitat conditions of subset $\mathrm{H}$ enhanced the common diatoms and Phaeocystis spp. mean abundances, as these species had greater affinities for these environmental habitat conditions. Phaeocystis spp. still managed to reach high abundance despite the increase of the relevant number of diatom species. Skeletonema spp. was the only common diatom species that was disfavored by the change in environmental habitat conditions, and better responded to the environmental habitat conditions of subset L.

A succession of the diatom subniche was observed in the two habitat subsets (Figure 7A and B), as expected from the niche analysis (Figure 4). In subset L, the late-winter early-spring species (Ske, Thn and Thg) were 
blooming first because they were affiliated with winter like conditions, i.e., low temperature, PAR and salinity, but high nutrient concentrations and turbidity. Then, Par was second to bloom followed by Pss, Gud, Gus and Phae (Figure 7A). The first species to appear in subset H was Ske, while Thn, Cha, Dit, Par and Nit appeared second. The succession of diatoms continued with Gud, Gus and Led (Figure 7B). In subset H, the subniche of Phaeocystis spp. overlapped most of the diatoms' niche positions, but still managed to have a larger niche breadth than in subset L. The diatom-Phaeocystis spp. succession did not take place in subset H, as Phaeocystis spp. managed to develop concomitantly with the diatom species (Figure 7B).

\subsection{Biological reducing factor:}

The Phaeocystis spp. subniche in subset L occupied $19 \%$ of the existing fundamental subniche. Therefore the biological constraint was equal to $81 \%$ (Figure 8B). The subniche occupation of Phaeocystis spp. in subset $\mathrm{H}$ within the existing fundamental subniche, represented $75 \%$. Thus, the subniche biological constraint was of $25 \%$ of the existing fundamental subniche (Figure 8A). Therefore, the unused available conditions of the Phaeocystis spp. existing fundamental subniche could have been occupied by competing diatom species, such as Skeletonema spp., Thalassionema nitzschioides, Thalassiosira gravida and the Pseudo-nitzschia seriata complex (Figure 8A). By contrast, the Phaeocystis spp. subniche overlapped the diatoms subniches in subset H (Figure 8B).

\section{Discussion:}

The OMI analysis revealed that nutrient concentrations (phosphate, silicate, nitrite, nitrate and ammonia) played an important role in the diatom community distribution (Figure 5A and 5C). Subset $\mathrm{H}$ was characterized both by lower nutrient concentrations and faster decreases than subset L (Figure $5 \mathrm{E}$ to $5 \mathrm{H}$ ). Therefore, the realized subniche of Phaeocystis spp. shifted in position and increased in breadth from subset L to $\mathrm{H}$. The diatom-Phaeocystis spp. succession occurred in subset L but not in $\mathrm{H}$. The realized subniche of Phaeocystis spp. seemed to be more controlled by the preceeding diatom community than by the subset habitat conditions. Furthermore, the increasing diversity in the diatom community exerted a lower biological constraint on the Phaeocystis spp. realized subniche. The results suggest that key diatom species possibly competed for resources with Phaeocystis spp., especially nitrogen, phosphate and light, but only when silicate was available. Hereafter, the robustness of actual hypotheses related to the Phaeocystis spp. niche in the literature are discussed followed by an examination of the possible biotic interaction explaining the fluctuating abundances. 
4.1. Phaeocystis spp. hypotheses:

The "silicate-Phaeocystis hypothesis" (Lancelot et al., 1987; Reid et al., 1990) has historically been a major explanation in the appearance of Phaeocystis spp. Environmental silicate concentration may determine the duration and stability of the diatom community. For instance, in both subsets, Phaeocystis spp. started to bloom when the silicate concentration dropped below $1.5 \mu \mathrm{mol} . \mathrm{L}^{-1}$. This threshold was reached later, in April, for subset L compared to March for subset H (see Figure 4). The "silicate-Phaeocystis hypothesis" (Lancelot et al., 1987; Reid et al., 1990) was only partly verified since Phaeocystis spp. was already present in the subset $\mathrm{H}$ in January, but did not bloom until the silicate concentration dropped below the threshold. The lower inorganic $\mathrm{P}$ demand of Phaeocystis spp. compared to diatoms (Riegman et al., 1992) could explain the constant presence in subset $\mathrm{H}$, characterized by low phosphate concentration from January to June. On the contrary, the "eutrophication hypothesis," which stipulates that Phaeocystis spp. abundance increases with higher N concentration, was not validated in this study. Subset L was characterized by higher concentrations of nitrite, nitrate and ammonia than subset $\mathrm{H}$, leading to a dominance of diatom species, but resulting in lower abundances of Phaeocystis spp. Furthermore, even though in subset L, leftover $\mathrm{N}$ from diatoms remained high, Phaeocystis did not bloom as much. Phaeocystis spp. might use the excess $\mathrm{N}$ leftover by the diatoms for growth, but this does not seem to determine the outbreaks of high abundance bloom events. The hypotheses linking Phaeocystis spp. appearances to N:Si (Tett et al., 1993; Tett and Walne, 1995) and N:P (Riegman et al., 1992) better at predicted the HAB timing. The maximum in N:Si or N:P corresponded to the start of Phaeocystis spp. bloom in both habitat subset conditions.

According to Borkman et al. (2016), higher salinity characterized the year of high $P$. pouchetii abundance and could also explain the years of high Phaeocystis spp. abundance. The higher salinity also reflected a lower precipitation flow rate from rivers and wind turbulence which can also take part in the turbidity level. Subset $\mathrm{H}$ was characterized by higher salinity and lower turbidity than subset L. Photosynthetically active radiation and temperature exhibited similar variations throughout the season. Temperature did not seem to impact Phaeocystis spp. appearance, because in subset H, Phaeocystis spp. was present in January, the coldest month $\left(6.5^{\circ} \mathrm{C}\right)$. The higher turbidity level in subset L suggested that the real amount of photosynthetically active radiation reaching the community was less than in subset H. Despite these conditions, Phaeocystis spp. still appeared under low PAR. This contradicts the hypothesis suggesting that Phaeocystis spp. dominates over diatoms when conditions resemble early summer along the Dutch coast (Peperzak, 1993). 


\subsection{Biotic interactions:}

The unused available conditions in the Phaeocystis spp. existing fundamental subniche is considered as the subset biotic reducing factor. Infection by viruses can also cause the biological constraint. Experimental results showed that $P$. pouchetii cell mortality rates by virus infection can reach $0.8 \mathrm{~d}^{-1}$ (Brussaard et al., 2005) but viruses do not infect healthy colonies (Bratbak et al., 1998).

Predation is a possible biological interaction that can affect Phaeocystis spp. forms. The high plasticity of Phaeocystis spp. capacity to change life forms, single-cells and colonies in response to grazing is well known (Nejstgaard et al., 2007). Futhermore, it can respond to different chemical cues released by different consumer species (Wang et al., 2015). For instance, Phaeocystis spp. is capable of switching from single-cells to colonies when grazed by ciliates (Long et al., 2007). Oppositely, when confronted by grazing copepods, Phaeocystis spp. can significantly decrease its colony numbers by 60-90\% (Long et al., 2007). Grazer abundances and diversity with different Phaeocystis spp. life forms should be considered in future studies, as they can directly impact HABs. The information on the different life-forms of Phaeocystis spp. and potential consumers were not available in the used dataset.

Another appropriate biological constraint in this study appeared to be competition, as the diatom community directly competes for resources with Phaeocystis spp. From late-winter to summer, the succession in blooms of the diatoms and their appearance depends on their preferences regarding environmental habitat conditions, further driving Phaeocystis spp. appearances and blooms. For instance, Skeletonema spp., T. nitzschioides, and T. gravida are known to be bloom forming species (Pratt, 1959; Smayda, 1958). They are considered as winter diatoms, according to their respective niche positions with preference for high nutrient concentrations and turbidity in association with low temperature, PAR and salinity. Their leading appearance, bloom magnitude and persistence determined the composition of the following community. The growth of Skeletonema spp. is known to be $25 \%$ faster when on sustained ammonia than on nitrate (Suksomjit et al., 2009; Tada et al., 2009). In addition, T. nitzschioides has also been shown to grow faster in ammonia and nitrate enriched conditions (Mochemadkar et al., 2013). In subset L, the high concentration of ammonia could have potentially helped Skeletonema spp., T. nitzschioides and T. gravida, which are pioneers, to grow faster and bloom, establishing their dominance in the community (Suksomjit et al., 2009; Tada et al., 2009) (Figure 5B). Furthermore, the P. seriata complex occurrence is also known to be nitrogen-limited, and more than capable of using ammonia (Fehling et al., 2006). The growth of Phaeocystis spp. is faster on ammonia than on nitrate (Tungaraza et al., 2003), but seemed to be out-competed by the diatoms in these environmental habitat conditions. Other factors, such as silicate and phosphate were not limiting and favored the diatoms. The establishment of the diatom species, with a preference for ammonia, possibly out-competed Phaeocystis spp., until the concentration of silicate became 
limiting, succeeded by the Phaeocystis spp. bloom.

In subset H, Phaeocystis spp. managed to flourish despite the presence of the five same species (Skeletonema spp., T. nitzschioides, Paralia sulcata, Guinardia delicatula and Guinardia striata) and four other species (Chaetoceros danicus, Ditylum brightwellii, Nitzschia longissima and Leptocylindrus danicus). The lower concentration of phosphate favored Phaeocystis spp.'s presence over diatoms likely through Phaeocystis spp.'s capacity to store phosphate within its colony matrix (Schoemann et al., 2001; Veldhuis et al., 1991) coupled with its lower P demand (Riegman et al., 1992). Moreover, the strong competitive ability of Phaeocystis spp. to obtain nitrogen (Riegman, 1995), along with lower concentration of silicate, inhibited the diatom community from bloomming as much as in subset L. Silicate limitation is thought to have resulted in an increase in magnitude and continuity Phaeocystis spp. blooms (Cadée and Hegeman, 1986; Lancelot, 1990; Lancelot et al., 1987). The silicate limitation dually selected diatom species which are less silicified, such as Leptocylindrus danicus, Chaetoceros danicus and Nitzschia longissima (Hasle et al., 1996). Furthermore, the N-source dependency of diatom silicate competitiveness, which determines the dominant species of the community (Ruth, 2012), reinforced the idea that Skeletonema spp., T. nitzschioides, T. gravida and P. seriata complex are decisive species for Phaeocystis spp. blooms.

The readjustment of nutrient concentrations rendered more than one resource limiting for the diatoms, resulting in a biodiversity increase (Hillebrand et al., 2014), as shown with the BV-step analysis (7 to 11 species from subset L to H). The niche expansion of Phaeocystis spp. (Tol: 0.59 and 0.64 for subset L and $\mathrm{H}$ respectively) can be partly explained by a relaxation in biological constraints (Table 2). The possible decrease in diatom competitive abilities resulted in the $25 \%$ of unused available environmental habitat conditions of the Phaeocystis spp. existing fundamental subniche.

\subsection{Further perspectives:}

Further investigations on diatom competitive abilities can be done experimentally (Ruth, 2012), and with the trait-based approach (Litchman and Klausmeier, 2008). The major components of the trait-based approach are the species' traits, environmental gradients, species' interactions and performance currency, which determines the species' niche within the community (McGill et al., 2006). In this study, the niche and subniche dynamics within the overall environmental habitat and subset environmental habitat conditions were studied for the entire community. Furthermore, the quantification of the biological constraints exerted on Phaeocystis spp.'s subniches was made possible. The direct relationships between traits and the species' response to environmental conditions (Lavorel and Garnier, 2002) can give us clues on the mechanisms driving community composition. In parallel, the patterns of functional-trait distribution (Bello, 2009; Weiher et al., 1998) can help explain how the community functional-traits controls the following Phaeocystis spp. bloom. Some methods, which link niche analysis and 
trait-based approaches already exist. The OMI-GAM analysis (Kleyer et al., 2012) determines species' responses to environmental conditions using the OMI analysis (Dolédec et al., 2000), and additionally could explain these responses using generalized additive models (GAM) with the traits as explanatory variables (Kleyer et al., 2012). Such analyses can help solve the Phaeocystis spp. riddle and other HAB related issues. In future studies, more precise ecological dynamics models could be built as the diatoms can be split into different functional groups. Models, such as the MIRO model (Lancelot et al., 2014), which also studies the spring-diatom-Phaeocystis bloom, considers diatoms as a large pool responding homogeneously to nutrient concentrations and/or ratios. As shown in this study, the mechanism driving the bloom of Phaeocystis spp. is multifactorial, suggesting a greater consideration of diatom diversity, including their respective traits and competitive abilities. Trait-based understanding of plankton distribution started with the paradox of the plankton (Hutchinson, 1961). Margalef was the first to understand the balance between the physical and nutritional forces relating to different life forms of phytoplankton with the classical "mandala" (Margalef, 1978; Margalef et al., 1979). Since then, the concept of the "mandala" has found its way into predicting HABs (Smayda and Reynolds, 2001) and nowadays incorporates twelve dimensions (Glibert, 2016). Herein, the environmental trajectory can help predict the high abundance events of Phaeocystis spp. in future "mandala" like models, by using the WitOMI calculations.

\section{Conclusion:}

The appearance of Phaeocystis spp. depends on multiple environmental factors, and moreover, on the preceding diatom community, which first appear in late winter. Within both habitat subsets, Phaeocystis spp. could have potentially realized a large subniche. The reduction and/or expansion of its subniche mostly depended on the winter environmental conditions and on the biological constraints. The competitive ability of diatoms appearing in late-winter are suspected to take part in the biological constraint of the Phaeocystis spp. subniche. The establishment of the leading species in the bloom succession, here Skeletonema spp., Thalassionema nitzschioides and Thalassiosira gravida seemed to be driven by nutrient concentration. Under non-limiting P environmental conditions, competition among diatoms for silicate will be N-source dependent. The high concentration of ammonia allowed a rapid growth and bloom of the later-winter diatoms (i.e. Skeletonema spp.) (Figure 3E), while Si limited their bloom magnitude. The effect of winter conditions on the Phaeocystis spp. bloom requires further investigation. The trait-based approach in relation with the community response to changing environmental conditions could be a promising field for studying the future of Harmful Algae Bloom. 


\section{Acknowledgements:}

First we want to thank the reviewers for their constructive comments on the study. We are thankful Diane Karasiewicz for proofreading the manuscript and Mathew J. McLean for editing. We would also like to thank Le Réseau d'Observation de Surveillance du Phytoplancton et des Phycotoxines and the Suivi Régional des Nutriments, partly supported by the Regional Water Agency. We want to thank all members of the REPHY program and the SRN network for providing expertise support. This research is part of a PhD Thesis funded by the Ministère de l'Education Nationale of France. This study was funded by the French government and the regional council "Hauts de France" in the framework of the CPER 2014-2020 project MARCO.

\section{References:}

Anderson, D.M., 2009. Approaches to monitoring, control and management of harmful algal blooms (habs). Ocean \& Coastal Management 52, 342-347. doi:http://dx.doi.org/10.1016/j.ocecoaman.2009.04.006

Bello, D., 2009. Partitioning of functional diversity reveals the scale and extent of trait convergence and divergence $475-486$.

Belin, C., and Neaud-Masson, N. 2012. Cahier de Procédures REPHY 2012-2013. Ifremer, Nantes. 81 pp.

Bianchi, T.S., Engelhaupt, E., Westman, P., Andrén, T., Rolff, C., Elmgren, R., 2000. Cyanobacterial blooms in the Baltic Sea: Natural or human-induced? Limnology and Oceanography 45, 716-726. doi:10.4319/lo.2000.45.3.0716

Blauw, A.N., Los, F.J., Huisman, J., Peperzak, L., 2010. Nuisance foam events and Phaeocystis globosa blooms in Dutch coastal waters analyzed with fuzzy logic. Journal of Marine Systems 83, 115-126. doi:10.1016/j.jmarsys.2010.05.003

Borkman, D.G., Libby, P.S., Mickelson, M.J., Turner, J.T., Jiang, M., 2016. Variability of Winter-Spring Bloom Phaeocystis pouchetii Abundance in Massachusetts Bay. Estuaries and Coasts 39, 1084-1099. doi:10.1007/s12237016-0065-5

Braak, C.J.F.T., 1986. Canonical correspondence analysis: A new eigenvector technique for multivariate direct gradient analysis. Ecology 67, 1167-1179.

Bradley, P.B., Sanderson, M.P., Nejstgaard, J.C., Sazhin, A.F., Frischer, M.E., Killberg-Thoreson, L.M., Verity, P.G., Campbell, L., Bronk, D.A., 2010. Nitrogen uptake by phytoplankton and bacteria during an induced 
Phaeocystis pouchetii bloom, measured using size fractionation and flow cytometric sorting. Aquatic Microbial Ecology 61, 89-104. doi:10.3354/ame01414

Bratbak, G., Jacobsen, a, Heldal, M., 1998. Viral lysis of Phaeocystis pouchetii and bacterial secondary production. Aquatic Microbial Ecology 16, 11-16. doi:10.3354/ame016011

Breton, E., Christaki, U., Bonato, S., Didry, M., Artigas, L., 2017. Functional trait variation and nitrogen use efficiency in temperate coastal phytoplankton. Marine Ecology Progress Series 563, 35-49. doi:10.3354/meps11974

Brussaard, C.P.D., Kuipers, B., Veldhuis, M.J.W., 2005. A mesocosm study of Phaeocystis globosa population dynamics: I. Regulatory role of viruses in bloom control. Harmful Algae 4, 859-874. doi:10.1016/j.hal.2004.12.015

Cadée, G.C., Hegeman, J., 1986. Seasonal and annual variation in phaeocystis pouchetii (haptophyceae) in the westernmost inlet of the Wadden Sea during the 1973 to 1985 period. Netherlands Journal of Sea Research 20, 29-36. doi:10.1016/0077-7579(86)90058-X

Cadée, G.C., Hegeman, J., 2002. Phytoplankton in the marsdiep at the end of the 20th century; 30 years monitoring biomass, primary production, and phaeocystis blooms. Journal of Sea Research 48, 97-110. doi:https://doi.org/10.1016/S1385-1101(02)00161-2

Calenge, C., Dufour, A.B., Maillard, D., 2005. K-select analysis: A new method to analyse habitat selection in radio-tracking studies. Ecological Modelling 186, 143-153. doi:10.1016/j.ecolmodel.2004.12.005

Clarke, K., Warwick, R., Laboratory, P.M., 2001. Change in marine communities: An approach to statistical analysis and interpretation. PRIMER-E Limited.

Davidson, K., Gowen, R.J., Tett, P., Bresnan, E., Harrison, P.J., McKinney, A., Milligan, S., Mills, D.K., Silke, J., Crooks, A.M., 2012. Harmful algal blooms: How strong is the evidence that nutrient ratios and forms influence their occurrence? Estuarine, Coastal and Shelf Science 115, 399-413. doi:10.1016/j.ecss.2012.09.019

Dolédec, S., Chessel, D., Gimaret-Carpentier, C., 2000. Niche separation in community analysis: A new method. Ecology 81, 2914. doi:10.1890/0012-9658(2000)081[2914:NSICAA]2.0.CO;2

Dray, S., Dufour, A.B., 2007. The ade4 Package: Implementing the Duality Diagram for Ecologists. Journal of Statistical Software 22, 1-20. doi:10.1.1.177.8850

Drijfhout, S., Bathiany, S., Beaulieu, C., Brovkin, V., Claussen, M., Huntingford, C., Scheffer, M., Sgubin, G., Swingedouw, D., 2015. Catalogue of abrupt shifts in Intergovernmental Panel on Climate Change climate models. Proceedings of the National Academy of Sciences 201511451. doi:10.1073/pnas.1511451112

Egge, J.K., Aksnes, D.L., 1992. Silicate as regulating nutrient in phytoplankton competition. Marine Ecology 
Progress Series 83, 281-289. doi:10.3354/meps083281

Fehling, J., Davidson, K., Bolch, C., Tett, P., 2006. Seasonally of Pseudo-nitzschia spp. (Bacillariophyceae) in western Scottish waters. Marine Ecology Progress Series 323, 91-105. doi:10.3354/meps323091

Fu, F.X., Tatters, A.O., Hutchins, D.A., 2012. Global change and the future of harmful algal blooms in the ocean. Marine Ecology Progress Series 470, 207-233. doi:10.3354/meps10047

Glibert, P.M., 2016. Margalef revisited: A new phytoplankton mandala incorporating twelve dimensions, including nutritional physiology. Harmful Algae 55, 25-30. doi:10.1016/j.hal.2016.01.008

Gowen, R., Tett, P., Bresnan, E., Davidson, K., McKinney, A., Harrison, P., Milligan, S., Mills, D., Silke, J., Crooks, A.-M., 2012. Anthropogenic nutrient enrichment and blooms of harmful phytoplankton, in: Oceanography and Marine Biology: An Annual Review. pp. 65-126. doi:10.1201/b12157-3

Grattepanche, J.D., Breton, E., Brylinski, J.M., Lecuyer, E., Christaki, U., 2011. Succession of primary producers and micrograzers in a coastal ecosystem dominated by Phaeocystis globosa blooms. Journal of Plankton Research 33, 37-50. doi:10.1093/plankt/fbq097

Hallegraeff, G.M., 2010. Ocean climate change, phytoplankton community responses, and harmful algal blooms: A formidable predictive challenge1. Journal of Phycology 46, 220-235. doi:10.1111/j.1529-8817.2010.00815.x

Hamm, C. E., Simson, D. A., Merkel, R., and Smetacek, V. (1999). Colonies of Phaeocystis globosa are protected by a thin but tough skin. Marine Ecology Progress Series, 187:101-111.

Hasle, G.R., Lange, C.B., Syvertsen, E.E., 1996. A review of Pseudo-nitzschia, with special reference to the skagerrak, north atlantic, and adjacent waters. Helgoländer Meeresuntersuchungen 50, 131-175. doi:10.1007/BF02367149 Hernández-Fariñas, T., Bacher, C., Soudant, D., Belin, C., Barillé, L., 2015. Assessing phytoplankton realized niches using a French national phytoplankton monitoring network. Estuarine, Coastal and Shelf Science 159, 15-27. doi:10.1016/j.ecss.2015.03.010

Hillebrand, H., Cowles, J.M., Lewandowska, A., Van de Waal, D.B., Plum, C., 2014. Think ratio! A stoichiometric view on biodiversity-ecosystem functioning research. Basic and Applied Ecology 15, 465-474. doi:10.1016/j.baae.2014.06.003

Houliez, E., Lizon, F., Artigas, L.F., Lefebvre, S., Schmitt, F.G., 2013. Spatio-temporal variability of phytoplankton photosynthetic activity in a macrotidal ecosystem (the Strait of Dover, eastern English Channel). Estuarine, 
Coastal and Shelf Science 129, 37-48. doi:10.1016/j.ecss.2013.06.009

Hutchinson, G.E., 1961. The paradox of the plankton. The American Naturalist 95, 137-145.

Jahnke, J., 1989. The light and temperature dependence of growth rate and elemental composition of Phaeocystis globosa scherffel and P. pouchetii (har.) lagerh. in batch cultures. Netherlands Journal of Sea Research $23,15-21$. doi:http://dx.doi.org/10.1016/0077-7579(89)90038-0

Jakobsen, H. H. and Tang, K. W., 2002. Effects of protozoan grazing on colony formation in Phaeocystis globosa (prymnesiophyceae) and the potential costs and benefits. Aquatic Microbial Ecology, 27(3):261-273.

Karasiewicz, S., Dolédec, S., Lefebvre, S., 2017. Within outlying mean indexes: Refining the omi analysis for the realized niche decomposition. PeerJ. doi:10.7717/peerj.3364

Kleyer, M., Dray, S., Bello, F., Lepš, J., Pakeman, R.J., Strauss, B., Thuiller, W., Lavorel, S., 2012. Assessing species and community functional responses to environmental gradients: which multivariate methods? Journal of Vegetation Science 23, 805-821. doi:10.1111/j.1654-1103.2012.01402.x

Kurekin, A.A., Miller, P.I., Van der Woerd, H.J., 2014. Satellite discrimination of Karenia mikimotoi and Phaeocystis harmful algal blooms in European coastal waters: Merged classification of ocean colour data. Harmful Algae 31, 163-176. doi:10.1016/j.hal.2013.11.003

Lacroix, G., Ruddick, K., Gypens, N., Lancelot, C., 2007. Modelling the relative impact of rivers (Scheldt/Rhine/Seine) and Western Channel waters on the nutrient and diatoms/Phaeocystis distributions in Belgian waters (Southern North Sea). Continental Shelf Research 27, 1422-1446. doi:10.1016/j.csr.2007.01.013

Lancelot, C., 1990. Phaeocystis blooms in the continental coastal areas of the Channel and the North Sea. In C. Lancelot, G. Billen, \& H. Barth (Eds.). Eutrophication and algal blooms in the North Sea coastal zones, the Baltic and adjacent areas : prediction and assessment of preventive actions 27-54.

Lancelot, C., Billen, G., Sournia, A., Weisse, T., Colijn, F., Veldhuis, M.J.W., Davies, A., Wassman, P., 1987. Phaeocystis blooms and nutrient enrichment in the continental coastal zones of the North Sea. Ambio 16, 38-46. Lancelot, C., Passy, P., Gypens, N., 2014. Model assessment of present-day Phaeocystis colony blooms in the Southern Bight of the North Sea (SBNS) by comparison with a reconstructed pristine situation. Harmful Algae 37, 172-182. doi:10.1016/j.hal.2014.05.017

Lancelot, C., Wassmann, P., Barth, H., 1994. Ecology of Phaeocystis-dominated ecosystems. Journal of Marine Systems 5, 1-4. doi:http://dx.doi.org/10.1016/0924-7963(94)90012-4

Lavorel, S., Garnier, E., 2002. Predicting changes in community composition and ecosystem functioning from 
plant traits : Functional Ecology 16, 545-556.

Lefebvre, A., Guiselin, N., Barbet, F., Artigas, F.L., 2011. Long-term hydrological and phytoplankton monitoring (19922007) of three potentially eutrophic systems in the eastern English Channel and the Southern Bight of the North Sea. ICES Journal of Marine Science 68, 2029-2043. doi:10.1093/icesjms/fsr149

Levasseur, M., Keller, M.D., Bonneau, E., D’Amours, D., Bellows, W.K., 1994. Oceanographic basis of a dms-related atlantic cod (Gadus morhua) fishery problem: Blackberry feed. Canadian Journal of Fisheries and Aquatic Sciences 51, 881-889. doi:10.1139/f94-087

Litchman, E., Klausmeier, C.a., 2008. Trait-Based Community Ecology of Phytoplankton. Annual Review of Ecology, Evolution, and Systematics 39, 615-639. doi:10.1146/annurev.ecolsys.39.110707.173549

Long, J. D., Smalley, G. W., Barsby, T., Anderson, J. T., and Hay, M. E., 2007. Chemical cues induce consumerspecific defenses in a bloom-forming marine phytoplankton. Proceedings of the National Academy of Sciences, 104(25):10512-10517.

Lundgren, V., Granéli, E., 2010. Grazer-induced defence in Phaeocystis globosa (Prymnesiophyceae): Influence of different nutrient conditions. Limnology and Oceanography 55, 1965-1976. doi:10.4319/lo.2010.55.5.1965

Manly, B.F.J., 1997. Randomization, bootstrap and monte carlo methods in biology. Chapman \& Hall, London. Margalef, R., 1978. Life-forms Phytoplankton as survival alternatives in an unstable environment. Oceanologica Acta 1, 463-509. doi:10.1007/BF00202661

Margalef, R., Estrada, M., Blasco, D., 1979. Functional morphology of organisms involved in red tides, as adapted to decaying turbulence. Elsevier.

McGill, B.J., Enquist, B.J., Weiher, E., Westoby, M., 2006. Rebuilding community ecology from functional traits. Trends in Ecology and Evolution 21, 178-185. doi:10.1016/j.tree.2006.02.002

Mochemadkar, S., Gauns, M., Pratihary, A., Thorat, B., Roy, R., Pai, I.K., Naqvi, S.W.A., 2013. Response of phytoplankton to nutrient enrichment with high growth rates in a tropical monsoonal estuary - Zuari estuary, India. Indian Journal of Marine Sciences 42, 314-325.

Nejstgaard, J. C., Tang, K. W., Steinke, M., Dutz, J., Koski, M., Antajan, E., and Long, J. D., 2007. Zooplankton grazing on phaeocystis: a quantitative review and future challenges. Biogeochemistry, 83(1-3):147-172.

Passy, P., Le Gendre, R., Garnier, J., Cugier, P., Callens, J., Paris, F., Billen, G., Riou, P., Romero, E., 2016. Eutrophication modelling chain for improved management strategies to prevent algal blooms in the Bay of Seine. 
Marine Ecology Progress Series 543, 107-125. doi:10.3354/meps11533

Peperzak, L., 1993. Daily irradiance governs growth rate and colony formation of Phaeocystis (Prymnesiophyceae). Journal of Plankton Research 15, 809-821. doi:10.1093/plankt/15.7.809

Peperzak, L., Colijn, F., Gieskes, W.W.C., Peeters, J.C.H., 1998. Development of the diatom-Phaeocystis spring bloom in the Dutch coastal zone of the North Sea: the silicon depletion versus the daily irradiance threshold hypothesis. Journal of Plankton Research 20, 517-537. doi:10.1093/plankt/20.3.517

Peterson, A.T., 2011. Ecological niches and geographic distributions (mpb-49). Princeton University Press.

Pratt, D.M., 1959. The Phytoplankton of Narragansett Bay. Limnology and Oceanography 4, 425-440.

R Core Team, 2013. R Core Team. R: A language and environment for statistical computing. R Foundation for Statistical Computing, Vienna, Austria.

Reid, P.C., Lancelot, C., Gieskes, W.W.C., Hagmeier, E., Weichart, G., 1990. Phytoplankton of the North Sea and its dynamics: a review. Netherlands Journal of Sea Research 26, 295-331. doi:10.1016/0077-7579(90)90094-w

Riegman, R., 1995. Nutrient-related selection mechanisms in marine phytoplankton communities and the impact of eutrophication on the planktonic food web. Water Science and Technology 32, 63-75. doi:http://dx.doi.org/10.1016/0273-1223(95)00682-6

Riegman, R., Noordeloos, A.A.M., Cadée, G.C., 1992. Phaeocystis blooms and eutrophication of the continental coastal zones of the north sea. Marine Biology 112, 479-484. doi:10.1007/BF00356293

Rogers, S., Lockwood, S., 1990. Observations on coastal fish fauna during a spring bloom of Phaeocystis pouchetii in the eastern irish sea. Journal of the Marine Biological Association of the United Kingdom 70, 249-253. doi:10.1017/S0025315400035360

Ruth, P.D. van, 2012. Size Dependent Competition in Centric Diatoms as a Function of Nitrogen and Silicon Availability. Open Journal of Marine Science 02, 33-42. doi:10.4236/ojms.2012.21005

Schoemann, V., Wollast, R., Chou, L., Lancelot, C., 2001. Effects of photosynthesis on the accumulation of Mn and Fe by Phaeocystis colonies. Limnology and Oceanography 46, 1065-1076. doi:10.4319/lo.2001.46.5.1065

Smayda, T.J., 1958. Biogeographical Studies of Marine Phytoplankto. Oikos 9, 158-191.

Smayda, T.J., Reynolds, C.S., 2001. Community assembly in marine phytoplankton: application of recent models to harmful dinoflagellate blooms. Journal of Plankton Res. 23, 447-461. doi:10.1093/plankt/23.5.447

SRN - Regional Observation and Monitoring program for Phytoplankton and Hydrology in the eastern English Channel (2017). SRN dataset - Regional Observation and Monitoring Program for Phytoplankton and Hydrology 
in the eastern English Channel. 1992-2016. SEANOE. doi:10.17882/50832

Suksomjit, M., Ichimi, K., Hamada, K.I., Yamada, M., Tada, K., Harrison, P.J., 2009. Ammonium accelerates the growth rate of Skeletonema spp. in the phytoplankton assemblage in a heavily eutrophic embayment, Dokai Bay, Japan. La mer 47, 89-101.

Tada, K., Suksomjit, M., Ichimi, K., Funaki, Y., Montani, S., Yamada, M., Harrison, P.J., 2009. Diatoms grow faster using ammonium in rapidly flushed eutrophic Dokai Bay, Japan. Journal of Oceanography 65, 885-891. doi:10.1007/s10872-009-0073-1

Tang, K. W. ,2003. Grazing and colony size development in Phaeocystis globosa (Prymnesiophyceae): the role of a chemical signal. Journal of Plankton Research, 25(7):831-842.

Ter Braak, C.J.F., 1987. The analysis of vegetation-environment relationships by canonical correspondence analysis. Vegetatio 69, 69-77. doi:10.1007/BF00038688

Tett, A.P.B., Joint, I.R., Purdie, D.A., Baars, M., Oosterhuis, S., Daneri, G., Mills, D.K., Plummer, D., Pomroy, A.J., Walne, A.W., Witte, H.J., Howarth, M.J., Lankester, R., 1993. Biological Consequences of Tidal Stirring Gradients in the North Sea [ and Discussion ] Biological consequences of tidal stirring gradients in the North Sea. Philosophical Transactions: Physical Sciences and Engineering 343, 493-508. doi:10.1098/rsta.1993.0061

Tett, P., Walne, A., 1995. Observations and simulations of hydrography, nutrients and plankton in the southern north sea. Ophelia 42, 371-416. doi:10.1080/00785326.1995.10431514

Tungaraza, C., Rousseau, V., Brion, N., Lancelot, C., Gichuki, J., Baeyens, W., Goeyens, L., 2003. Contrasting nitrogen uptake by diatom and Phaeocystis-dominated phytoplankton assemblages in the North Sea. Journal of Experimental Marine Biology and Ecology 292, 19-41. doi:10.1016/S0022-0981(03)00145-X

Utermöhl, H. 1958. Zur Vervollkommnung der quantitativen Phytoplankton-Methodik. Mitteilungen Internationale Vereinigung Theoretische und Angewandte Limnologie, 9: 1-38.

Veldhuis, M.J.W., Colijn, F., Admiraal, W., 1991. Phosphate Utilization in Phaeocystis pouchetii (Haptophyceae). Marine Ecology Pubblicazioni Della Stazione Zoologica Di Napoli I 12, 53-62.

Wang, X., Wang, Y., Ou, L., He, X., and Chen, D., 2015. Allocation costs associated with induced defense in Phaeocystis globosa (prymnesiophyceae): the effects of nutrient availability. Scientific reports, 5 .

Weiher, E., Clarke, G.D.P., Keddy, P.A., 1998. Community assembly rules, morphological dispersion, and the coexistence of plant species. Oikos 81, 309-322.

Wells, M.L., Trainer, V.L., Smayda, T.J., Karlson, B.S.O., Trick, C.G., Kudela, R.M., Ishikawa, A., Bernard, S., 
517 Wulff, A., Anderson, D.M., Cochlan, W.P., 2015. Harmful algal blooms and climate change: Learning from the past and present to forecast the future. Harmful Algae 49, 68-93. doi:10.1016/j.hal.2015.07.009

Yin, K., 2003. Influence of monsoons and oceanographic processes on red tides in Hong Kong waters. Marine 520

Ecology Progress Series 262, 27-41. doi:10.3354/meps262027 


\section{List of Figures}

1 Map of North of France with the main station location of the French REPHY-IFREMER network

2 The subniche concept from Karasiewicz et al. (2017). $\mathbf{E}_{1}$ and $\mathbf{E}_{2}$ are the environmental gradients calculated after an ordination technique. $\mathbf{E}$ is the realized environmental space (filled light orange minimum convex polygon). $\mathbf{N}_{R}$ is the species' realized niche (dotted dark orange contour). $\mathbf{K}$ is the subset realized environmental space (blue minimum convex polygon). $\mathbf{S}_{P}$ is the existing fundamental subniche (the red contour)-a union of $\mathbf{S}_{B}$ and $\mathbf{S}_{R} . \mathbf{S}_{B}$ is the subset biotic reducing factor (the part of $\mathbf{K}$ found within the orange contour), or biological constraint, and $\mathbf{S}_{R}$ is the realized subniche (the green minimum convex polygon) $\ldots \ldots \ldots \ldots$

3 Temporal variation of the annual mean abundance of Phaeocystis spp. (cell.L ${ }^{-1}$ ) from 1996 to 2012. The dashed line represents the upper threshold $\left(160\right.$ cell. $\left.\mathrm{L}^{-1}\right)$ and the dotted line represents the lower threshold $\left(50\right.$ cell. $\left.\mathrm{L}^{-1}\right)$. Abundance was then divided the abundance in three categories (Low, intermediate, high). Only high (empty triangles) and low (filled triangles) annual mean abundance events were kept for the rest of the study . . . . . . . . . . . . . .

4 Monthly mean $( \pm \mathrm{SD}$ ) of each environmental variable for the subset $\mathrm{H}$ (empty circles) and L (filled circles), low and high annual mean abundance of Phaeocystis spp., respectively. . . . . . . . . .

5 OMI analysis of the 11 diatom species and Phaeocystis spp. A) The orange polygon represents the overall habitat environmental space. The species' labels represent the species' niche positions (see Table 1 for codes). B) The environment trajectory, from January to December, under the two subsets L (blue arrows) and H (green arrows). C) The canonical weights of environmental variables. 27

6 Phaeocystis spp. subniches' dynamics. A) The illustration of the Phaeocystis spp. subniches' dynamics found within the niche (the dotted orange contour). The green polygon represents Phaeocystis spp. subniches. The orange polygon represents the overall habitat environmental space. The labels represent the subniches' positions and the arrows represent the marginality. B and $\mathrm{C}$ are the graphical representations of Phaeocystis spp. subniches within the environmental subsets (blue polygons). The red contour represents the Phaeocystis spp. existing fundamental subniche. The red dots represent the mean environmental conditions found within each subset. .

$7 \quad$ Phaeocystis spp. subniches within the two subsets L and $\mathrm{H}$. The green polygon represents the Phaeocystis spp. subniche. The orange polygon represents the habitat conditions space. The dotted orange contour represents the Phaeocystis spp. realized niche. The red contour represents the Phaeocystis spp. existing fundamental subniche. The labels represent the subniches' positions of the relevant species resulting from the BV-step analysis. The arrows represent the trajectory taken by the habitat conditions from January to December under their respective subsets. . . . .

8 Phaeocystis spp. and possible competitors' subniches within the two subsets L and H. The orange polygon represents the habitat conditions space. The blue polygon represents the subset habitat conditions space. The green polygon represents the Phaeocystis spp. subniche. The red contour represents the Phaeocystis spp. existing fundamental subniche. The colored dots and the corresponding polygon represent the subniche position and breadth respectively. Not all relevant species of each subset were represented for the sake of clarity. . . . . . . . . . . . 


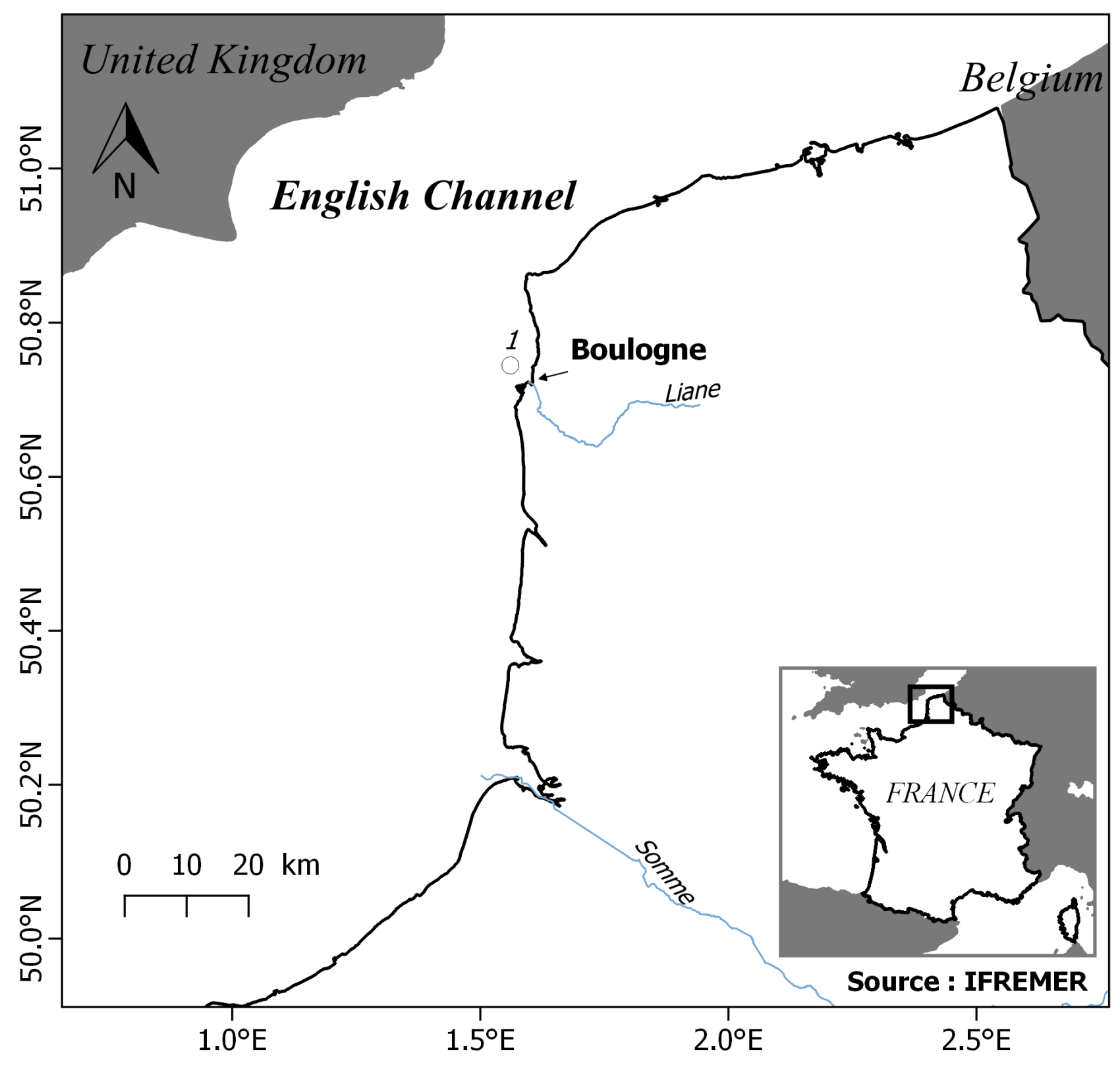

Figure 1: Map of North of France with the main station location of the French REPHY-IFREMER network 


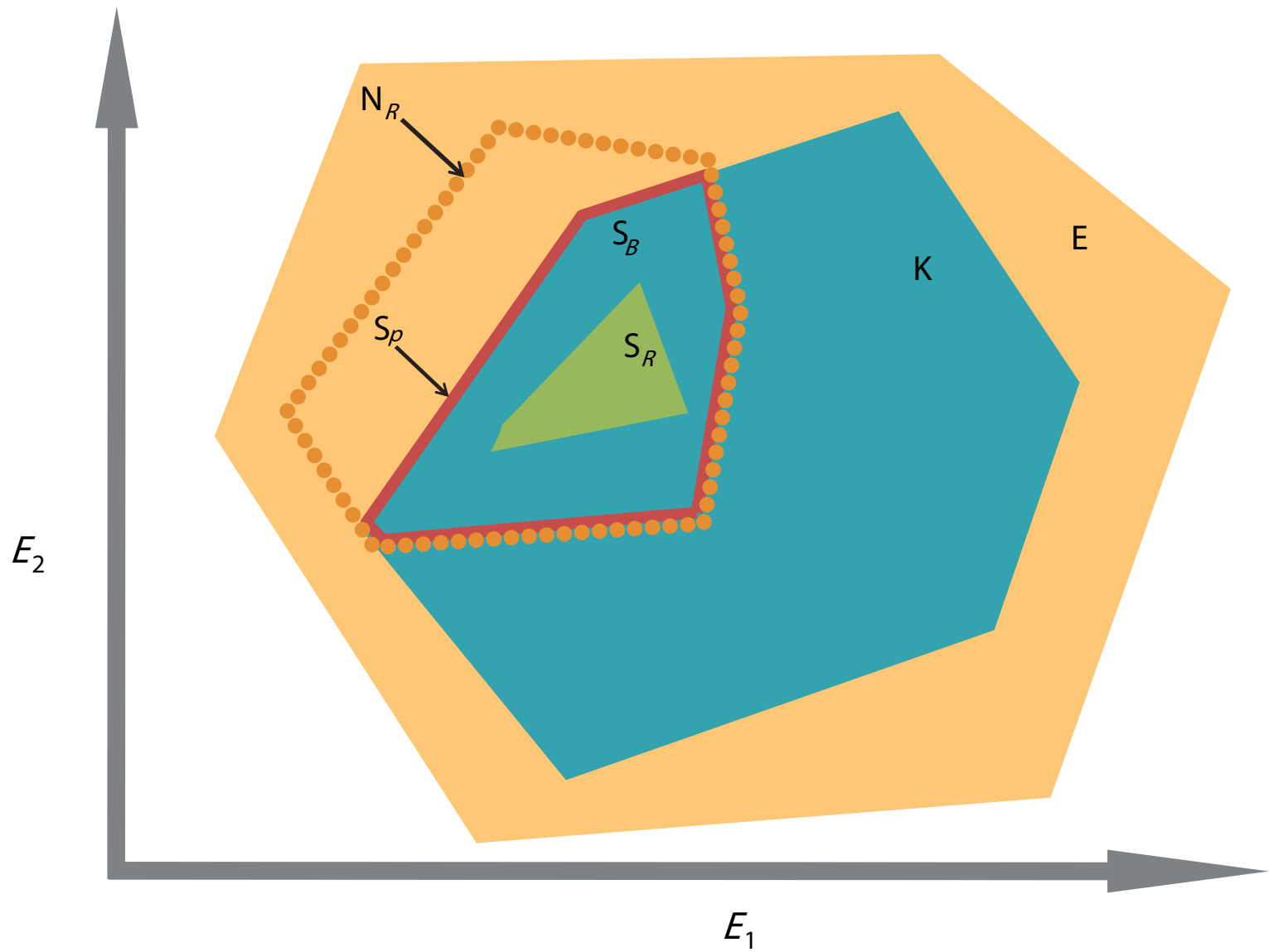

Figure 2: The subniche concept from Karasiewicz et al. (2017). $\mathbf{E}_{1}$ and $\mathbf{E}_{2}$ are the environmental gradients calculated after an ordination technique. $\mathbf{E}$ is the realized environmental space (filled light orange minimum convex polygon). $\mathbf{N}_{R}$ is the species' realized niche (dotted dark orange contour). $\mathbf{K}$ is the subset realized environmental space (blue minimum convex polygon). $\mathbf{S}_{P}$ is the existing fundamental subniche (the red contour)-a union of $\mathbf{S}_{B}$ and $\mathbf{S}_{R} \cdot \mathbf{S}_{B}$ is the subset biotic reducing factor (the part of $\mathbf{K}$ found within the orange contour), or biological constraint, and $\mathbf{S}_{R}$ is the realized subniche (the green minimum convex polygon). 


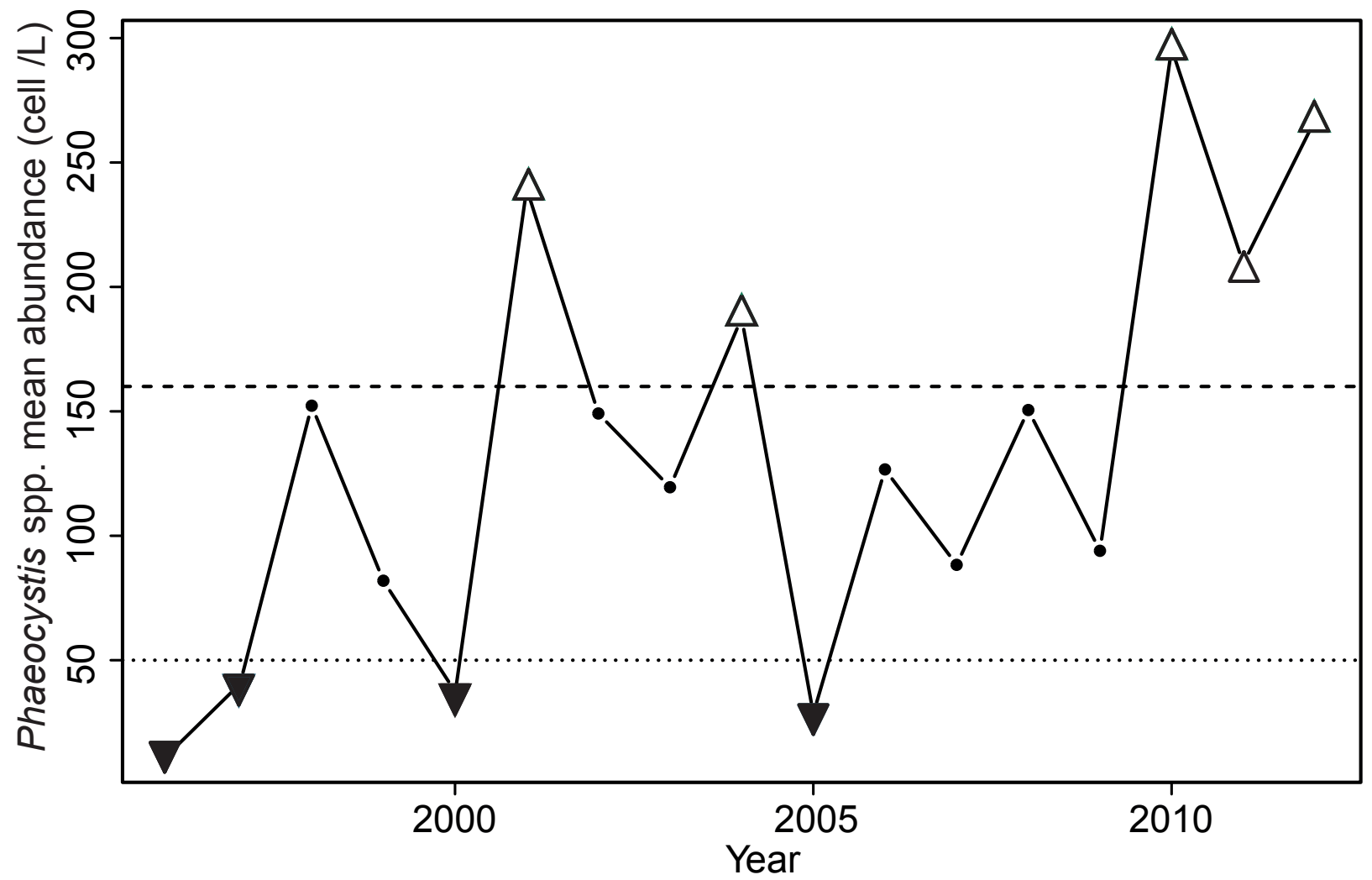

Figure 3: Temporal variation of the annual mean abundance of Phaeocystis spp. (cell.L ${ }^{-1}$ ) from 1996 to 2012 . The dashed line represents the upper threshold $\left(160\right.$ cell. $\left.\mathrm{L}^{-1}\right)$ and the dotted line represents the lower threshold $\left(50\right.$ cell. $\left.\mathrm{L}^{-1}\right)$. Abundance was then divided the abundance in three categories (Low, intermediate, high). Only high (empty triangles) and low (filled triangles) annual mean abundance events were kept for the rest of the study 

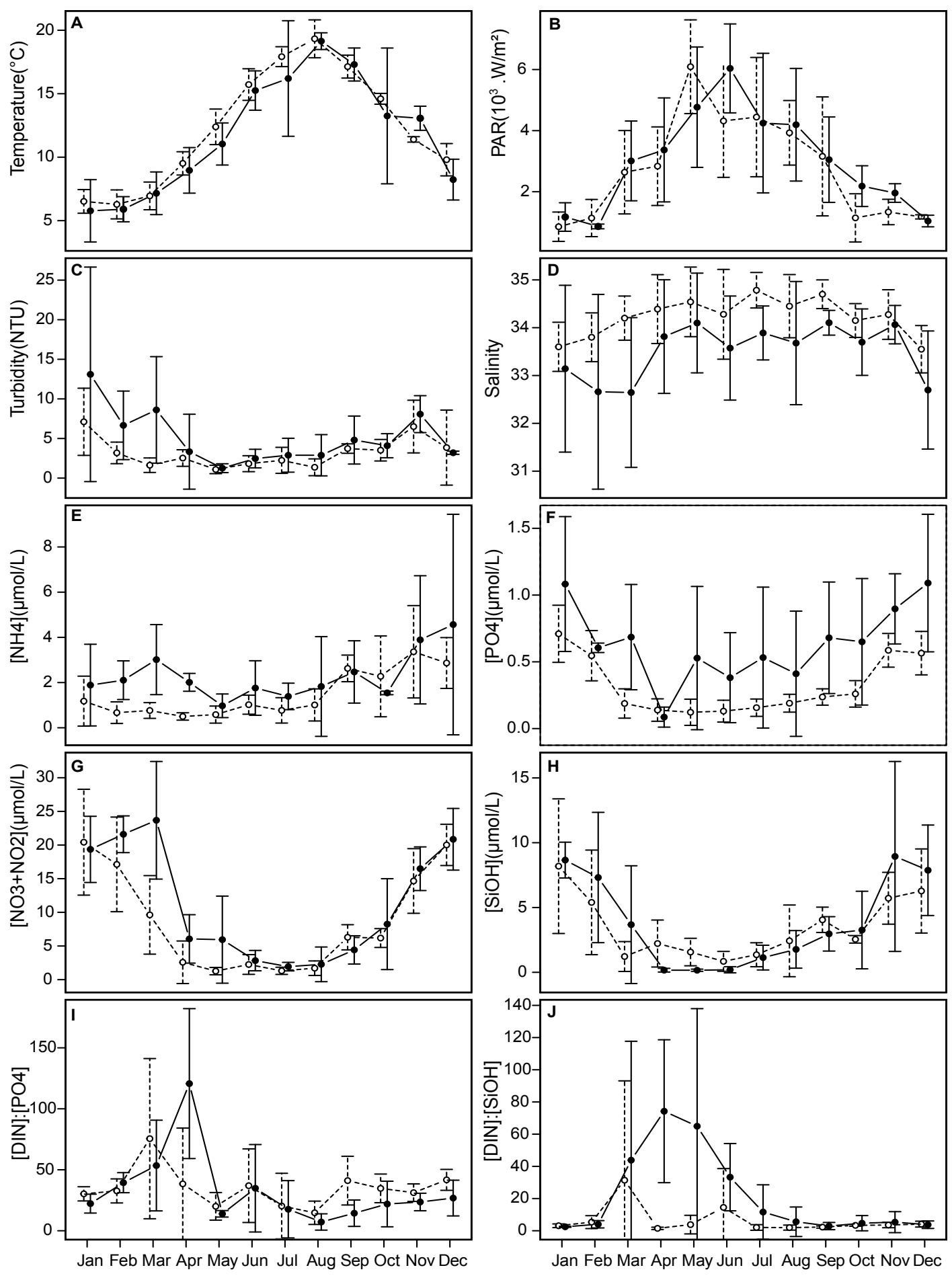

Months 
Figure 4: Monthly mean ( $\pm \mathrm{SD}$ ) of each environmental variable for the subset $\mathrm{H}$ (empty circles) and L (filled circles), low and high annual mean abundance of Phaeocystis spp., respectively. 

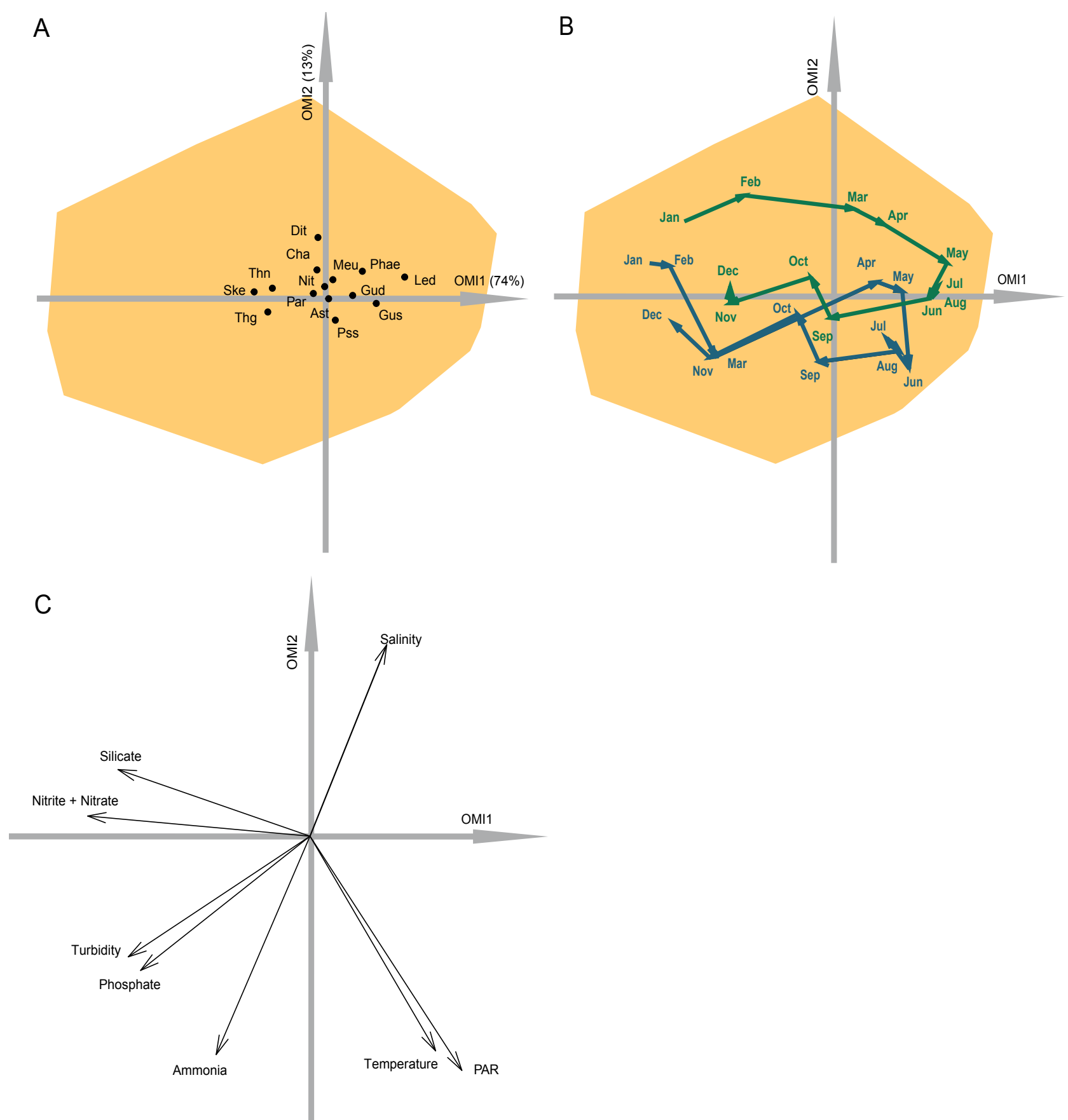

Figure 5: OMI analysis of the 11 diatom species and Phaeocystis spp. A) The orange polygon represents the overall habitat environmental space. The species' labels represent the species' niche positions (see Table 1 for codes). B) The environment trajectory, from January to December, under the two subsets L (blue arrows) and H (green arrows). C) The canonical weights of environmental variables. 

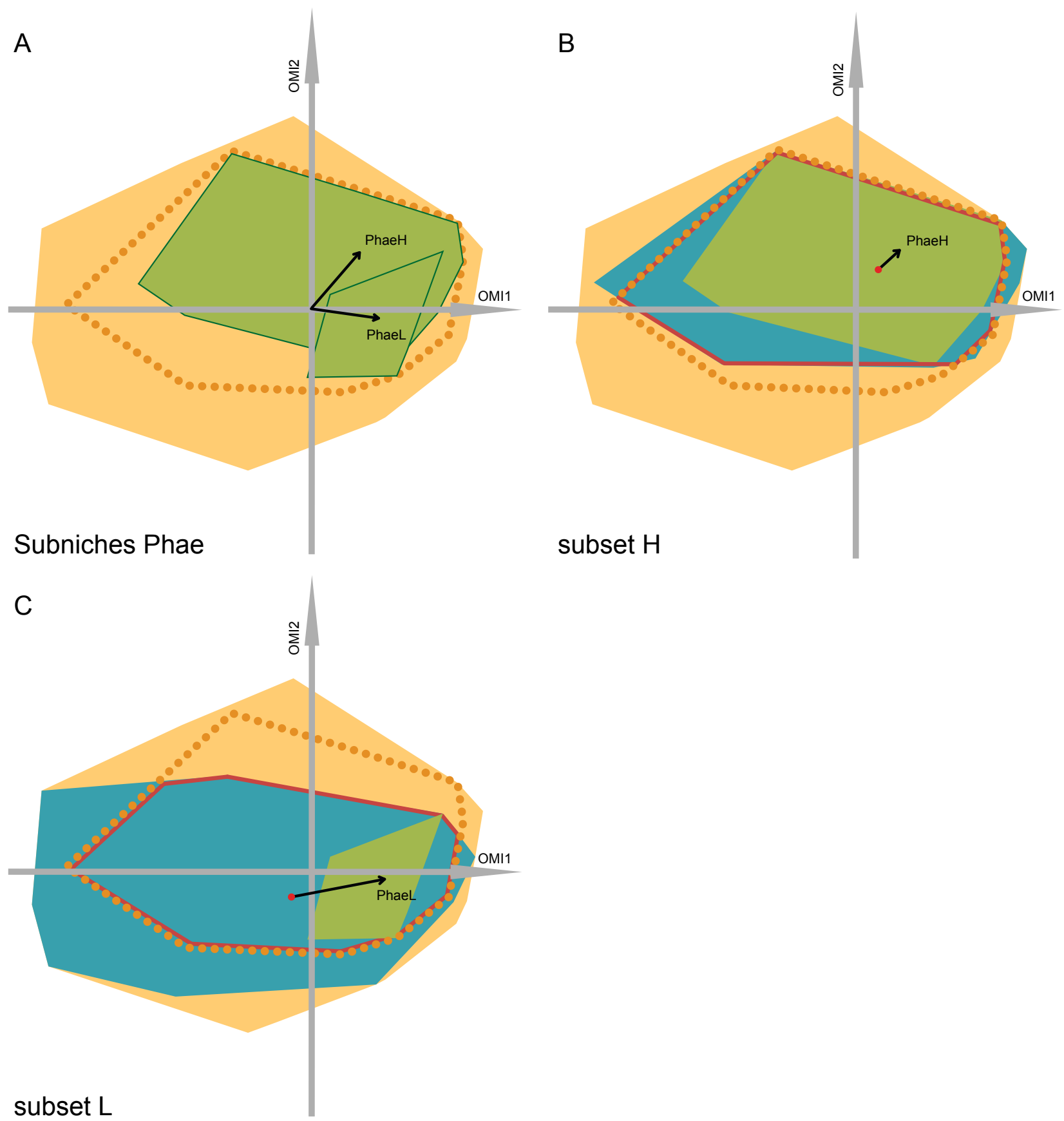

Figure 6: Phaeocystis spp. subniches' dynamics. A) The illustration of the Phaeocystis spp. subniches' dynamics found within the niche (the dotted orange contour). The green polygon represents Phaeocystis spp. subniches. The orange polygon represents the overall habitat environmental space. The labels represent the subniches' positions and the arrows represent the marginality. B and C are the graphical representations of Phaeocystis spp. subniches within the environmental subsets (blue polygons). The red contour represents the Phaeocystis spp. existing fundamental subniche. The red dots represent the mean environmental conditions found within each subset. 

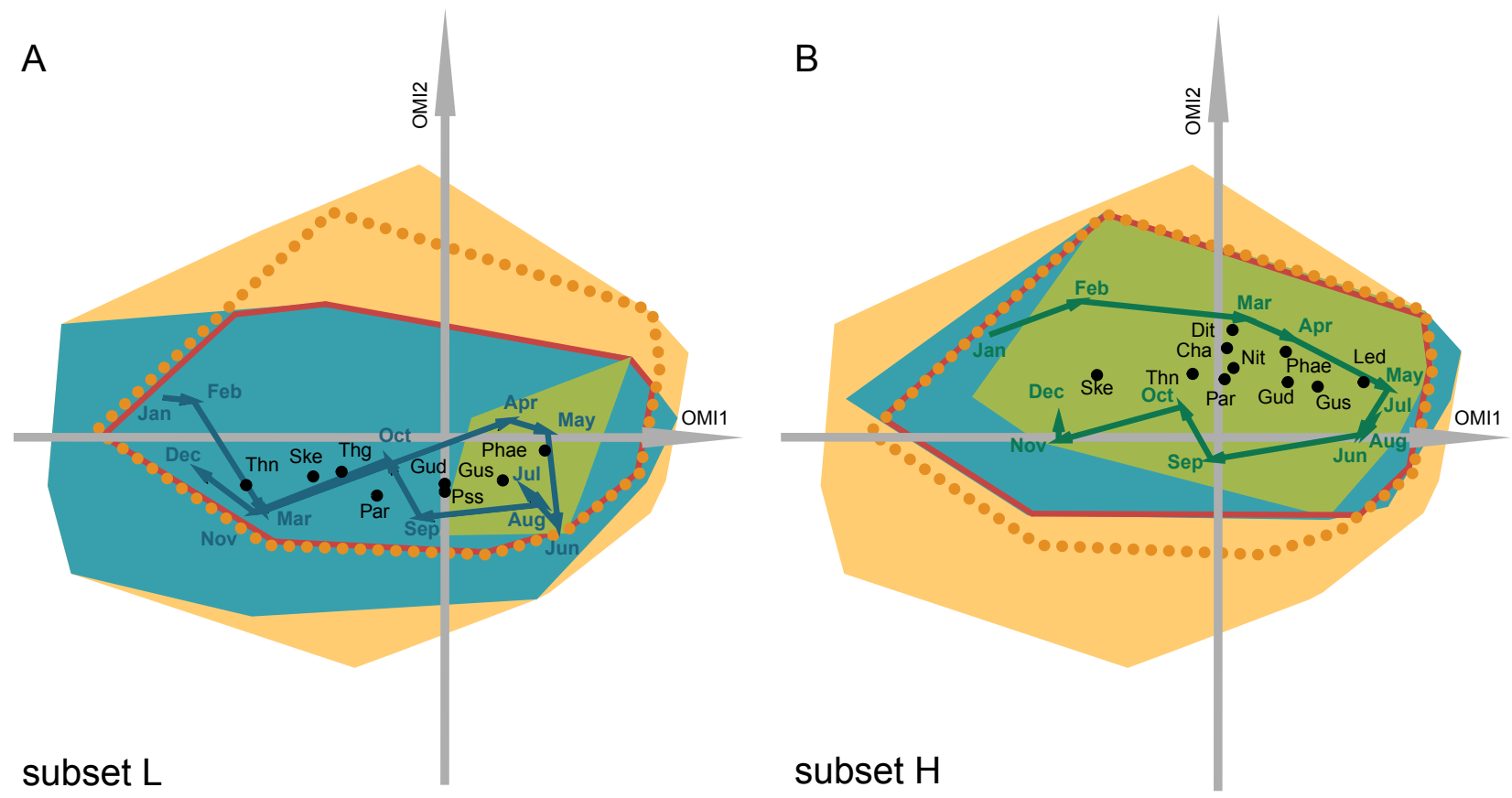

Figure 7: Phaeocystis spp. subniches within the two subsets L and H. The green polygon represents the Phaeocystis spp. subniche. The orange polygon represents the habitat conditions space. The dotted orange contour represents the Phaeocystis spp. realized niche. The red contour represents the Phaeocystis spp. existing fundamental subniche. The labels represent the subniches' positions of the relevant species resulting from the BV-step analysis. The arrows represent the trajectory taken by the habitat conditions from January to December under their respective subsets. 

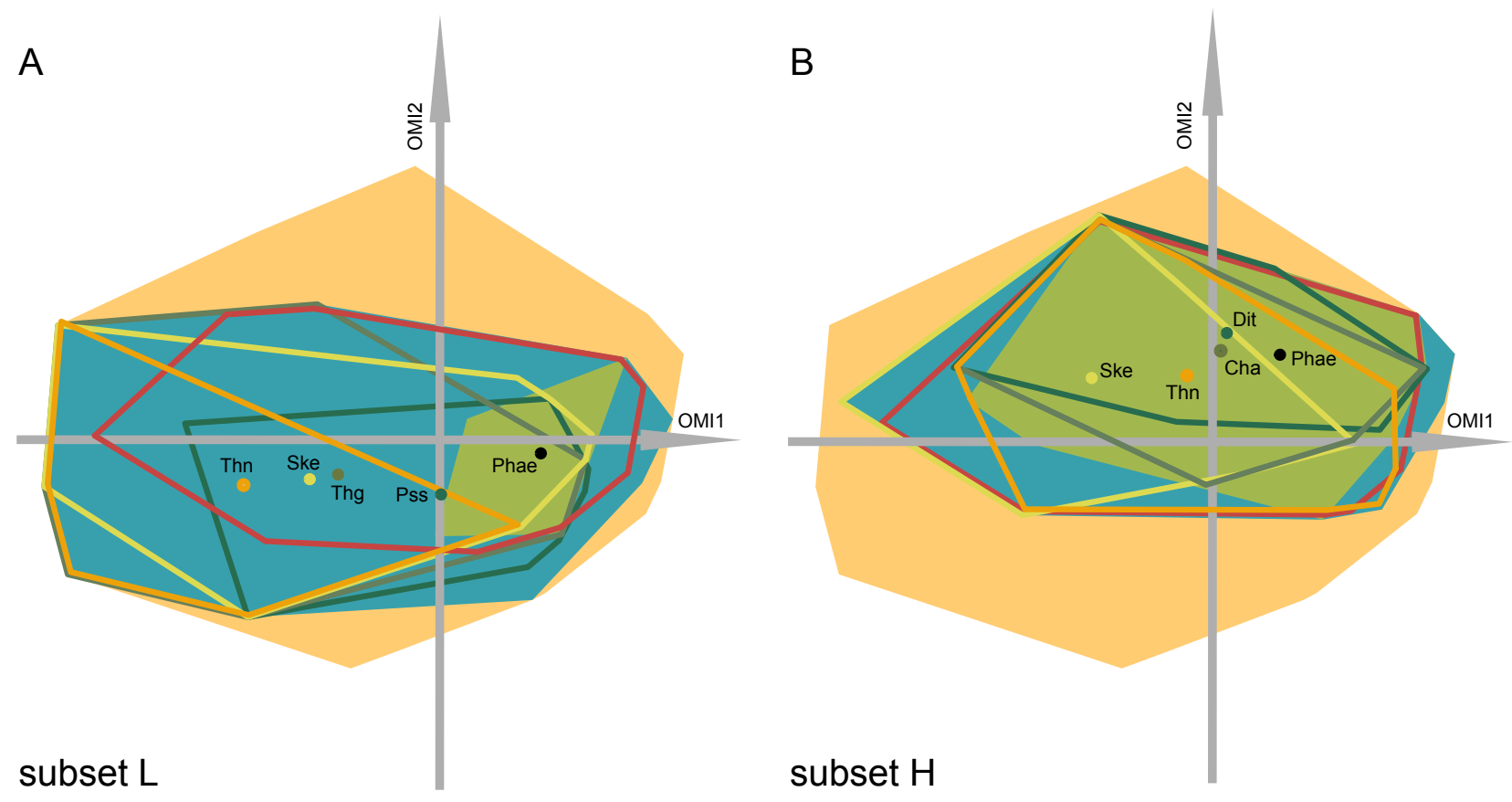

Figure 8: Phaeocystis spp. and possible competitors' subniches within the two subsets L and H. The orange polygon represents the habitat conditions space. The blue polygon represents the subset habitat conditions space. The green polygon represents the Phaeocystis spp. subniche. The red contour represents the Phaeocystis spp. existing fundamental subniche. The colored dots and the corresponding polygon represent the subniche position and breadth respectively. Not all relevant species of each subset were represented for the sake of clarity. 


\section{List of Tables}

1 Niche parameters calculated with the OMI analysis for 11 diatoms species and Phaeocystis spp. The parameters are the inertia, the marginality (OMI), the tolerance (Tol) and the residual tolerance (Rtol). The $P$ values were calculated with 1000 permutations, see methods for further details. . . . . . . . . . . . . . . . . . . . . . .

2 Subniche parameters of the 11 diatom species of interest and Phaeocystis spp. The marginality (WitOMI), tolerance (TOL) and mean abundance were calculated under the two subsets, L and H. The niche parameters were calculated from $G$ and $G_{K}$. For code see Table 1. All subniches were significant $(P \leq 0.001)$. - not applicable means that the species were absent in one of the two subsets, or not significant with the BV step analysis. For further details see Materials and Methods. 33 
Table 1: Niche parameters calculated with the OMI analysis for 11 diatoms species and Phaeocystis spp. The parameters are the inertia, the marginality (OMI), the tolerance (Tol) and the residual tolerance (Rtol). The $P$ values were calculated with 1000 permutations, see methods for further details.

\begin{tabular}{lcrrrrr}
\hline Species & Code & Inertia & OMI & Tol & Rtol & $P$ \\
\hline Chaetoceros danicus & Cha & 7.09 & 0.36 & 0.98 & 5.76 & 0.03 \\
Ditylum brightwellii & Dit & 7.48 & 1.07 & 1.14 & 5.26 & 0.00 \\
Guinardia delicatula & Gud & 7.28 & 0.22 & 2.51 & 4.56 & $<0.001$ \\
Guinardia striata & Gus & 6.65 & 0.79 & 1.62 & 4.24 & $<0.001$ \\
Leptocylindrus danicus & Led & 6.61 & 2.23 & 1.31 & 3.07 & $<0.001$ \\
Nitzschia longissima & Nit & 7.73 & 0.06 & 0.77 & 6.89 & 0.05 \\
Paralia sulcata & Par & 7.82 & 0.09 & 2.24 & 5.49 & 0.00 \\
Pseudo-nitzschia seriata complex & Pss & 7.25 & 0.20 & 0.96 & 6.09 & 0.01 \\
Skeletonema spp. & Ske & 10.12 & 1.64 & 3.52 & 4.96 & $<0.001$ \\
Thalassionema nitzschioides & Thn & 9.02 & 0.93 & 3.35 & 4.74 & $<0.001$ \\
Thalassiosira gravida & Thg & 9.23 & 1.15 & 3.14 & 4.95 & $<0.001$ \\
Phaeocystis spp. & Phae & 6.58 & 0.83 & 1.36 & 4.39 & $<0.001$ \\
\hline
\end{tabular}


Table 2: Subniche parameters of the 11 diatom species of interest and Phaeocystis spp. The marginality (WitOMI), tolerance (TOL) and mean abundance were calculated under the two subsets, L and $\mathrm{H}$. The niche parameters were calculated from $G$ and $G_{K}$. For code see Table 1. All subniches were significant $(P \leq 0.001)$. - not applicable means that the species were absent in one of the two subsets, or not significant with the BV step analysis. For further details see Materials and Methods.

\begin{tabular}{|c|c|c|c|c|c|c|c|c|c|c|}
\hline \multirow{3}{*}{$\begin{array}{l}\text { Code } \\
\text { Origin } \\
\text { Data subset }\end{array}$} & \multicolumn{4}{|c|}{ WitOMI } & \multicolumn{4}{|c|}{ Tol } & \multirow{2}{*}{\multicolumn{2}{|c|}{$\begin{array}{l}\text { Mean abundance } \\
\quad\left(\text { cells. } L^{-1}\right)\end{array}$}} \\
\hline & \multicolumn{2}{|c|}{$G$} & \multicolumn{2}{|c|}{$G_{K}$} & \multicolumn{2}{|c|}{$G$} & \multicolumn{2}{|c|}{$G_{K}$} & & \\
\hline & $\mathrm{L}$ & $\mathrm{H}$ & $\mathrm{L}$ & $\mathrm{H}$ & $\mathrm{L}$ & $\mathrm{H}$ & $\mathrm{L}$ & $\mathrm{H}$ & $\mathrm{L}$ & $\mathrm{H}$ \\
\hline Cha & - & 1.34 & - & 0.31 & - & 0.56 & - & 1.95 & - & 111 \\
\hline Dit & - & 1.93 & - & 0.58 & - & 0.45 & - & 1.26 & - & 100 \\
\hline Gud & 0.6 & 1.26 & 0.2 & 0.16 & 0.62 & 1.28 & 2.97 & 1.97 & 295 & 298 \\
\hline Gus & 1.09 & 2.07 & 1.3 & 0.65 & 1.43 & 0.91 & 2.05 & 1.49 & 226 & 222 \\
\hline Led & - & 4.11 & - & 2.05 & - & 0.61 & - & 0.65 & - & 118 \\
\hline Nit & - & 0.86 & - & 0.14 & - & 0.58 & - & 2.14 & - & 268 \\
\hline Par & 1.48 & 0.63 & 0.52 & 0.16 & 1.73 & 0.45 & 1.68 & 2.85 & 138 & 284 \\
\hline Pss & 0.83 & - & 0.28 & - & 0.6 & - & 1.69 & - & 173 & - \\
\hline Ske & 3.17 & 2.88 & 1.71 & 3.85 & 3.83 & 2.14 & 3.86 & 2.45 & 206 & 126 \\
\hline Thn & 6.61 & 0.77 & 4.36 & 0.63 & 2.17 & 1.19 & 2.22 & 3.03 & 163 & 197 \\
\hline Thg & 2.02 & - & 0.78 & - & 3.83 & - & 4.13 & - & 139 & - \\
\hline Phae & 2.64 & 2.11 & 3.24 & 0.59 & 0.59 & 0.64 & 0.67 & 0.46 & 29 & 237 \\
\hline
\end{tabular}

